drinks, although more dilute than formerly, at more restricted hours and greater cost. Most of those directly interested in the trade were happy, and the rest of the country saw less home misery and fewer drunkards in the streets.

It is impossible in this place to write about other activities of Lord d'Abernon, but any one man who could be chairman of the Betting Control Board, of the Medical Research Council, the Industrial Health Research Board, the Lawn Tennis Association, the Thoroughbred Horse Breeders' Association, a trustee of the Tate and the National Galleries, clearly had many attributes of greatness. In the public eye, the most outstanding post held by Lord d'Abernon was his appointment in 1920 as the first British Ambassador to the German Republic, a position he held until 1926. Here again it is impossible to write of his work, but it is no secret that his ambassadorship was very successful and that in the eyes of those Germans who were in a position to know, he was regarded in Germany for several years as its uncrowned king. There was real friendship and trust between d'Abernon and Stresemann in those days, and the death of Stresemann at a crucial moment in international negotiations was always regarded by d'Abernon as one of the major calamities of AngloGerman relations.

After returning from Berlin, d'Abernon wrote a statistical report about conditions in Germany, which aroused great interest, and one result of this was his election to the presidency of the Royal Statistical Society. He was also made chairman of the Royal Commission on Museums and Galleries, and in this capacity rendered substantial services to science. In 1931 he was elected chairman of the Medical Research Council, but, shortly after his appointment, he unfortunately developed the first signs of the illness which incapacitated him, so that for the last five or six years of his life he was unable to participate in public life. It may be said, however, that during the early period of his chairmanship of the Medical Research Council, he broke all precedent by insisting on knowing personally individual workers of the Council, and on discussing with them their problems under investigation. Some of the friendships he formed with scientific men he retained to his death, and he never lost interest in their subject. His belief in the power of science to supply facts and knowledge necessary for the efficiency of the State was implicit, and towards the end of his life he wrote: "given persevering research and the proper use of available knowledge, we can confidently hope that within a generation every individual might be allowed to have the full development of health belonging to his inborn potentiality." Had we a few more men of affairs who, in addition to paying lip service to scientific methods and results, had the same belief in science and the prepared mind to make use of it, Great Britain would be a better place in which to live.

In 1934 Lord d'Abernon was elected to the fellow. ship of the Royal Society, a distinction he greatly prized.

Edward Mellanby.

\section{Mr. T. E. Barr Smith}

By the death of Tom Elder Barr Smith which was recently announced by cable, South Australia has lost one of the best of her citizens and the University of Adelaide a good counsellor and generous friend.
T. E. Barr Smith received his school education at St. Peter's College, Adelaide, whence he proceeded to Trinity Hall, Cambridge. He was the senior member of the firm of Elder Smith \& Co., shipowners and wool merchants of Adelaide, with large pastoral interests in South Australia. Boing intimately acquainted with both the production and marketing of wool, alive to the bearings of scientific research on the former and trusted by everyone, he played a useful part in the development of Australia's primary industry along sound lines.

Education and culture in South Australia owe much to the public spirit and generosity of members of the firm of Elder Smith \& Co. When the University of Adelaide was founded in 1874, Sir Thomas Elder provided one half of the cash endowment, and Robert Barr Smith, Tom's father, endowed the library. Some twenty years later, Sir Thomas Elder presented a further handsome sum to found and endow a chair of music and a Conservatorium. Another partner, Peter Waite, left his fortune to endow a chair of agriculture and a research institute as part of the Department of Agriculture. The Waite Institute at Glen Osmond on the outskirts of the city is well equipped and provided for, and one of the most flourishing research institutes in the British Commonwealth. Yet another member of the firm of Elder Smith, Walter Young, served for many years as treasurer, and the University owes much to his wise guidance, particularly during the difficult years of the world economic crisis at the beginning of last decade, when the financial stability of Australia was shaken.

Tom Barr Smith's gifts to the University of Adelaide were generous and frequent. A vigorous young University must continuously expand its activities, and he contributed handsomely towards many of its developments. His largest single gift was a new home for the library. The Barr Smith Library is a fine separate building with ample provision for expansion. It is convenient, comfortable and comely. It serves as a noble monument to keep green the memory of one of the best friends of the University in the minds of future generations of alumni.

Tom Barr Smith was genuinely interested in science and learning, and found enjoyment in the companionship of those with similar tastes. Many scientific visitors to Australia will remember the charming hospitality extended to them by Mr. and Mrs. Barr Smith at their home at the foot of the Adelaide Hills, and their enjoyment of the company of this kindly, modest and shrewd Australian.

Charles Martin.

WE regret to announce the following deaths :

Prof. P. Flemming, emeritus professor of ophthalmic medicine and surgery in University College, London, known also for his work in archæology, on December 19.

Capt. T. A. Joyce, O.B.E., formerly deputy keeper in charge of the Sub-Department of Ethnography, British Museum, on January 3, aged sixty-three.

Prof. S. M. G. Ure, assistant professor of chemical engineering in the Imperial College of Science and Engineering, and reader in the University of London, on December 25.

Prof. 'T. Henry Wilson, formerly King's professor of midwifery in Trinity College, Dublin, and president of the Royal College of Physicians of Ireland during 1926-27, on November 20, aged seventy-eight. 